Zoran Janjušević, Vladislav Matković, Mladen Bugarčić, Miroslav Sokić, Branislav Marković, Vaso Manojlović, Aleksandra Patarić

Institute for Technology of Nuclear and Other Mineral Raw Materials, Belgrade, Serbia
Scientific paper

ISSN 0351-9465, E-ISSN 2466-2585

UDC:669.283'17

doi: $10.5937 /$ ZasMat1801102J

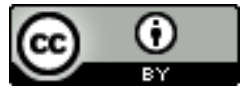

Zastita Materijala 59 (1)

$100-107$ (2018)

\title{
Molybdenum recovery as alloying agent from waste molybdenum solution
}

\begin{abstract}
The present work reports the commercialization of a recycling process of spent acid from filament tungsten wire plant to recover molybdenum (VI)-oxide and further utilizing this product for alloying cast iron. First part of the process consists of ammonia gas neutralization of spent acid containing molybdenum, crystallization and filtration of ammonium molybdate, drying and roasting to produce a commercial grade molybdic-trioxide powder (molybdenum mass fraction 59.2 mas\%). Second part of the process consists of grey cast alloying with $\mathrm{MoO}_{3}$ in inducing furnace. Final product was hardened iron alloy with high yield of molybdenum recovery (up to $86 \%$ ).
\end{abstract}

Keywords: spent acid, ammonia neutralization, molybdenum-trioxide, alloying, cast iron.

\section{INTRODUCTION}

During the production of filament tungsten wires for incandescent light bulbs a great amount of spent acid is obtained which contains by main high concentration of sulphuric and nitric acid (500$700 \mathrm{~g} / \mathrm{L}$ of both acids) and also soluble molybdenum-sulfate, in mass concentration of 20$100 \mathrm{~g} / \mathrm{L}$ of Mo. The manufacture of tungsten filaments for electric lamps is performed by double coiling of tungsten wire coils around molybdenum mandrel rods and after that is separated from the coil by dissolution of molybdenum in a reagent composed of nitric and sulphuric acids [1]. This solution would cause huge contamination of soil and water if it was released directly in sewerage system. On the other hand this waste solution could be of great economic interest since it could be refined into chemical fertilizers $[2,3]$. Also there are other secondary sources of molybdenum which could be valorized, such as hydrodesulphurization (HDS) catalysts in petroleum industry [4-7], a scrap $[8,9]$ secondary mineral sources such as low grade molybdenite concentrate generated as byproduct of uranium mining and milling operations [10].

${ }^{*}$ Corresponding author: Mladen Bugarčić

E-mail:m.bugarcic@itnms.ac.rs

Paper received: 31. 10. 2017.

Paper accepted: 30. 11. 2017.

Paper is available on the website:

www.idk.org.rs/journal
Molybdenum compounds and his alloys could be used in a form of $\mathrm{MoO}_{3}$ and $\mathrm{MoO}_{2}$ as a catalyst in hydrocarbon reforming process [11,12], or as a electrocatalyst in fuel cell applications together with $\mathrm{Pt}$ and $\mathrm{Ru}$ [13] or as silicides of molybdenum for high temperature structural purposes [14]. However, statistic from the LME (London Metal Exchange) shows us that the most amount of produced molybdenum is used in metallurgy (about $86 \%)$ and the rest is used in chemical application. From this bigger part of the pie the biggest consumers are steelworks of constructional and stainless steels followed by producers of tool and high speed steels, cast irons and super alloys [15]. So far only a few papers have been reported on the recovery of molybdenum from the spent acid. Pak et al [1] utilized these solutions and produced molybdenum powder from the molybdenum (VI)oxide they gain after precipitating of molybdenumsulphate as ammonium-molybdate and then roasting this salt which decompose to ammonia, water and molybdenum (VI)-oxide. Also there have been some earlier papers which refer on this subject, pioneer research paper was published by Kulkarni [16], and he has evaluated a number of techniques as distillation, solvent extraction, ion exchange and direct ammonium-molybdate precipitation. He came to conclusion that the simplest and the best technique is ammonia gas precipitation. The second relevant article is the work of McCarthy [17] who boiled spent acid and crystalize 70 mas \% of molybdenum as molybdic 
acid. This process requires stainless reactors which can withstand the high corrosive effect of the spent acids on high temperatures. Thermodynamic of cast iron alloying process with $\mathrm{MoO}_{3}$ is basically chemical reduction of the molybdenum ( $\mathrm{VI}$ )-oxide in the presence of triiron carbide to dimolybdenum carbide. Cast iron could be alloyed with molybdenum or his oxides as it confirms phase diagram of Fe-Mo-C system, Figure 1 [18]. Free energy of this multicomponent system changes almost linearly as a function of temperature. In the Table $1[19,20]$ is shown this function in reasonable temperature range when reaction 1 occurs.

$$
7 \mathrm{Fe}_{3} \mathrm{C}+2 \mathrm{MoO}_{3} \rightarrow \mathrm{Mo}_{2} \mathrm{C}+21 \mathrm{Fe}+6 \mathrm{CO}
$$

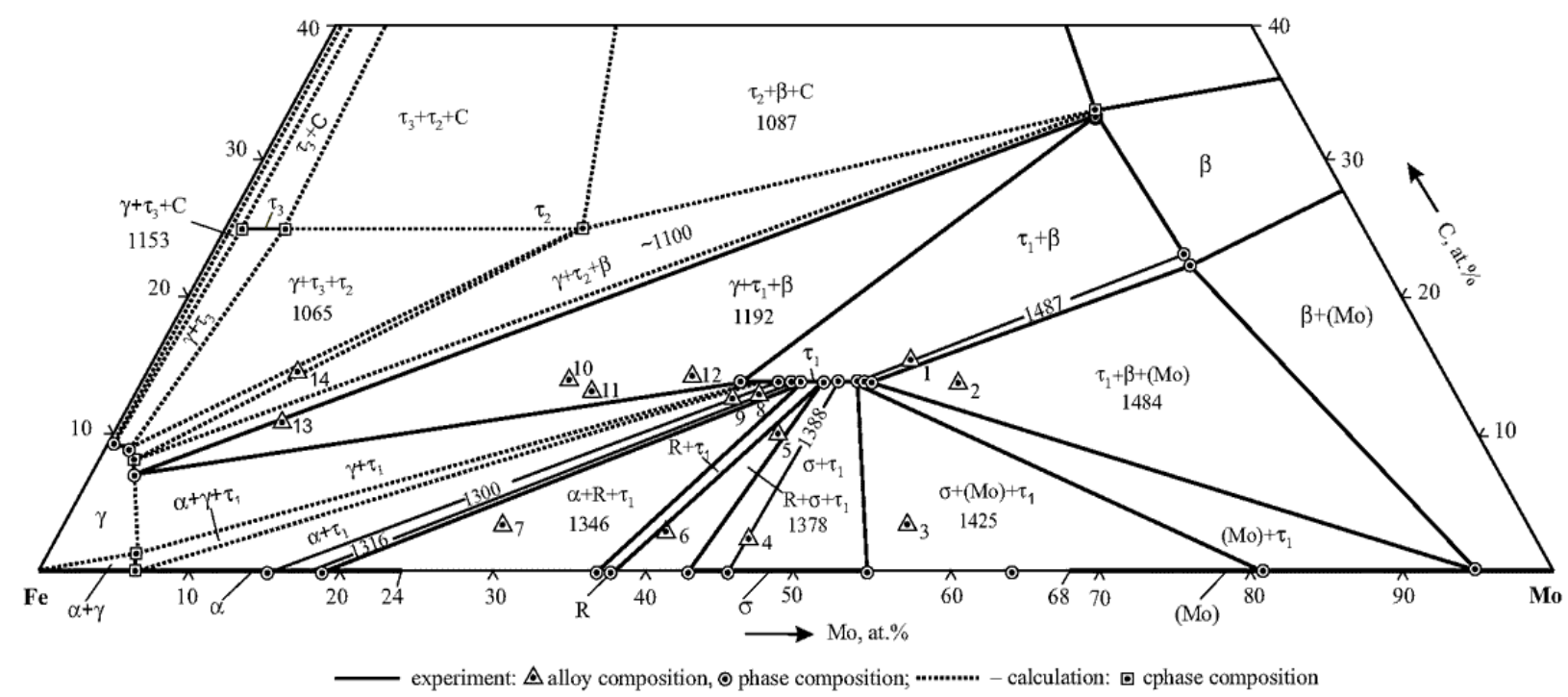

Figure 1. Solidus surface projection of the Fe-Mo-C phase diagram [18]

Slika 1. Solidus projekcija faznog dijagrama Fe-Mo-C [18]

Table 1. Free energy change as a function of temperature for the reaction (1) [19,20]

Tabela 1. Promena slobodne energije kao funkcija temperature za reakciju $(1)[19,20]$

\begin{tabular}{|c|c|c|c|c|c|c|c|}
\hline $\mathrm{t} /{ }^{\circ} \mathrm{C}$ & 400 & 500 & 600 & 700 & 800 & 900 & 1000 \\
\hline$\Delta \mathrm{G} / \mathrm{kJ}$ & 344.96 & 261.92 & 178.21 & 92.57 & 4.824 & -76.07 & -159.15 \\
\hline
\end{tabular}

Completion of Table 1:

\begin{tabular}{|c|c|c|c|c|c|c|c|}
\hline $\mathrm{t} /{ }^{\circ} \mathrm{C}$ & 1100 & 1200 & 1300 & 1400 & 1500 & 1600 & 1700 \\
\hline$\Delta \mathrm{G} / \mathrm{kJ}$ & -241.59 & -323.43 & -404.76 & -485.78 & -567.74 & -660.18 & -758.76 \\
\hline
\end{tabular}

Using the Mo ( $\mathrm{VI})$ compounds for producing high speed steels may be met in papers $[21,22]$ but there were not earlier attempts of alloying the grey cast iron with molybdenum (VI)-oxide. Main aim in this research paper was to produce molybdenum (VI)-oxide by ammonia gas neutralization method $[16,23]$ and then to find the procedure for utilizing this compound for alloying the cast iron without using other reducing agents in order to obtain harder iron alloys.

\section{EXPERIMENTAL PROCEDURES}

Whole experimental work in this research may be divided in two steps. First step is synthesis of molybdenum (VI)-oxide from the mixture of spent acids which contains, by main sulphuric and nitric acid and significant amount of molybdenum- sulphate and negligible amount of tungsten in the sulphate form too. Figure 2 shows the scheme of the ammonia gas precipitation process followed by pyrolysis of precipitated salt so final product is molybdenum (VI)-oxide.

Initial waste molybdenum solution composition was determined measuring its $\mathrm{pH}$ value, and titrating of the twenty times diluted sample by standard sodium-hydroxide (Sigma Aldrich, Analytical, Puriss) solution, concentration $0.1042 \mathrm{M}$. Content of Molybdenum and tungsten was determined using the Flame Atomic Absorption Spectrometer Perkin Elmer AAnalyst 300. Processes of dilution, neutralization and purification were all done in glass beaker nominal volume 2 liters, mixing of the reaction solution was performed using the magnetic stirrer. Amount of water used for dilution 
of the waste solution was 3:1 showed as volume ratio. For the neutralization and precipitation of the diluted waste solution was used $10 \%$ ammonia solution, neutralization was performed until $\mathrm{pH}$ value of solution hasn't risen to 2,50 . Process of precipitation was performed at the $85^{\circ} \mathrm{C}$, this temperature was maintained adding ammonia solution at the room temperature at the volume rate of $5 \mathrm{ml} / \mathrm{min}$ and regulating magnetic stirrer rpm at 400. The end of the precipitation was decided when the $\mathrm{pH}$ value of the reaction mixture reached 5,80 .

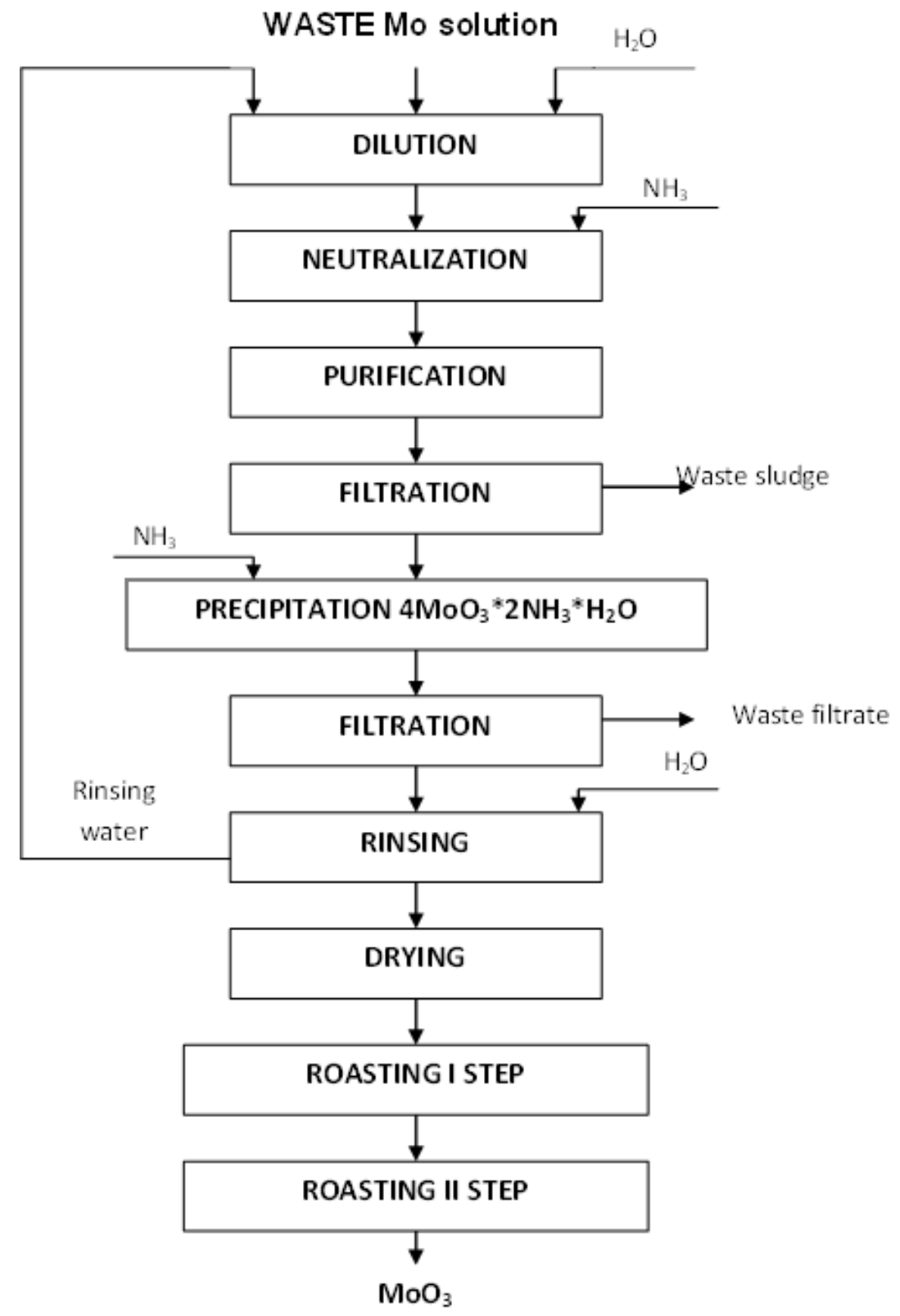

Figure 2. Flow sheet for $\mathrm{MoO}_{3}$ recovery from spent acid

Slika 2. Blok dijagram iskorišćenja $\mathrm{MoO}_{3}$ iz potrošene kiseline

After precipitation the solution with precipitated crystals were drained to centrifuge hydroextractor to collect all the crystals as sludge. Filtration was done by Buchner funnel. Waste filtrate contains dissolved ammonium-sulphate and ammonium- nitrate by main and small amounts of the excess ammonia. These two salts ensue in the reactions of neutralization (2) and (3) and they could be utilized as fertilizers: 


$$
\begin{aligned}
& 2 \mathrm{NH}_{3}+\mathrm{H}_{2} \mathrm{SO}_{4} \rightarrow\left(\mathrm{NH}_{4}\right)_{2} \mathrm{SO}_{4} \\
& \mathrm{NH}_{3}+\mathrm{HNO}_{3} \rightarrow \mathrm{NH}_{4} \mathrm{NO}_{3}
\end{aligned}
$$

After rinsing of the feed and its drying, the roasting was performed in the two steps. First step was done at the $120{ }^{\circ} \mathrm{C}$ for the 30 minutes after reaching this temperature and second step at the $500{ }^{\circ} \mathrm{C}$ for the 1 hour both roasting processes was done in the air conditions. The formed product was chemically analyzed by the AAS Perkin Elmer AAnalyst 300 and silica was determined by standard alkaline melting gravimetric method. Particle size distribution was determined too using the dry sieve analysis.

The second step in experimental procedures was the alloying of the gray cast iron with molybdenum (VI)-oxide which formation was described in previous section. The chemical composition of cast iron was determined with the same instrumental method as the $\mathrm{MoO}_{3}$ powder. The samples used for alloying (Ligrap Foundry) were made of $95 \%$ pearlite which is determined by Carl Zeiss Jenapol-U, light optical microscope. All the samples had low phosphorus content (bellow 0,2 mas \%) which was needed so the molybdenum wouldn't spend as the molybdenum-phosphate.
Also their hardness was measured by standard Brinell hardness test method before alloying and after alloying. Alloying process were performed in vacuum induction furnace "Balzers" nominally power $15 \mathrm{~kW}$ on the frequency of $9,4 \mathrm{kHz}$, the volume of the furnace ceramic pot was $0,5 \mathrm{dm}^{3}$. On the Figure 3 it is shown scheme of the used induction furnace. All the alloying experiments were performed with next process parameters:

\section{- Temperature $1450^{\circ} \mathrm{C}$}

- Time of alloying (measured from the moment the $\mathrm{MoO}_{3}$ powder was inserted in furnace until last amount was inserted) of 15 minutes

- Mass of the gray cast iron sample of 300 grams

During the alloying experiments vacuum wasn't applied, so the furnace worked on air conditions. Casting of the formed cast iron was performed after removing the slag into mold in the shape of cylinder, dimensions of the cylinder was $d=38 \mathrm{~mm}$ and $\mathrm{h}=60 \mathrm{~mm}$. The mold was made from graphite and it was coated with zirconium.

The variable in these experiments was mass fraction of the $\mathrm{MoO}_{3}$ relative to mass of cast iron during the blending together these two components.

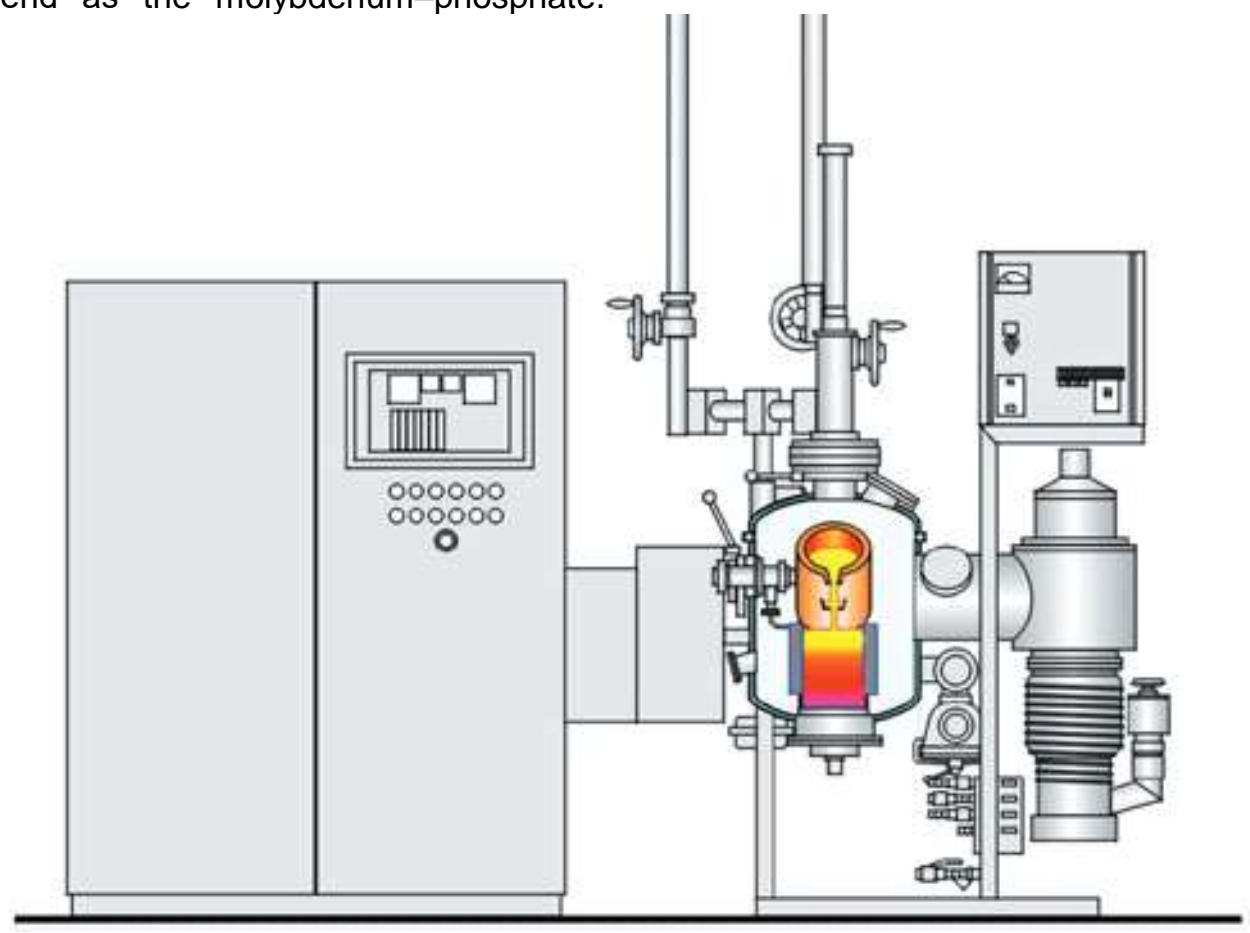

Figure 3. Schematic display of the induction furnace "Balzers"

Slika 3. Šematski prikaz indukcione peći "Balzers"

\section{RESULTS AND DISCUSSION}

Summarized results of the waste acidic molybdenum solution chemical composition showed as mass conceration of its most represented components has shown in Table 2. 
Table 2. Chemical composition of the three samples of waste acid received from local lamp industry

Tabela 2. Hemijski sastav tri uzorka otpadne kiseline dobijene iz lokalne industrije sijalica

\begin{tabular}{|l|c|c|c|c|}
\hline \multicolumn{1}{|c|}{$/$} & $\mathrm{H}_{2} \mathrm{SO}_{4} / \mathrm{g} \mathrm{l}^{-1}$ & $\mathrm{HNO}_{3} / \mathrm{g} \mathrm{l}^{-1}$ & $\mathrm{Mo} / \mathrm{g} \mathrm{l}^{-1}$ & $\mathrm{~W} / \mathrm{g} \mathrm{l}^{-1}$ \\
\hline Sample 1 & 326 & 194 & 97 & 0.1 \\
\hline Sample 2 & 380 & 184 & 63 & 0.4 \\
\hline Sample 3 & 440 & 207 & 42 & 1.0 \\
\hline Mean value & 382 & 195 & 67 & 0.5 \\
\hline
\end{tabular}

These results show that extent of acid used for neutralization, make the waste solution richer in tungsten content and molybdenum content gets lower when the acids concentrations get higher. For the neutralization and precipitation of ammonium-molybdate mixture of these samples was prepared using equivalent volumes of each. For neutralization of $200,0 \mathrm{ml}$ of diluted waste solution to the target $\mathrm{pH}$ was needed $110,6 \mathrm{ml}$ of ammonia solution. For precipitation of the $200 \mathrm{ml}$ of filtrate it was needed $32,9 \mathrm{ml}$ of the same ammonia solution.

After granulometric and chemical analysis of the powder formed in two step roasting process followed results were received.

Granulometric analysis on the sieves says that all the powder particles were below $10 \mu \mathrm{m}$ in their biggest diameter. Chemical analysis of the $\mathrm{MoO}_{3}$ powder is showed in the Table 3.

\section{Table 3. Chemical composition of the $\mathrm{MoO}_{3}$ powder}

Tabela 3. Hemijski sastav praha $\mathrm{MoO}_{3}$

\begin{tabular}{|c|c|c|c|c|c|}
\hline Component & Mo & W & Fe & Cu & Si \\
\hline Mass fraction/ \% & 59,2 & 0,60 & 0,22 & 0,17 & 3,31 \\
\hline
\end{tabular}

Table 4. Chemical composition of gray cast iron prior to alloying

Tabela 4. Hemijski sastav sivog liva pre legiranja

\begin{tabular}{|c|c|c|c|c|c|c|c|c|c|}
\hline Component & $\mathrm{C}$ & $\mathrm{Si}$ & $\mathrm{Mn}$ & $\mathrm{P}$ & $\mathrm{S}$ & $\mathrm{Cr}$ & $\mathrm{Al}$ & $\mathrm{Cu}$ & $\mathrm{Fe}$ \\
\hline Content/ mas $\%$ & 3,48 & 1,93 & 0,82 & 0,041 & 0,12 & 0,10 & 0,01 & 0,12 & 93,2 \\
\hline
\end{tabular}

Table 5. Summarized results of chemical analysis of the iron alloy samples after alloying process

Tabela 5. Sumarni rezultati hemijske analize uzoraka železne legure nakon procesa legiranja

\begin{tabular}{|c|c|c|c|c|c|c|c|c|c|}
\hline $\begin{array}{c}\text { Mass fraction of } \\
\begin{array}{c}\text { MoO } \\
\text { cast iron/ } \%\end{array}\end{array}$ & $\mathrm{Mo}$ & $\mathrm{Si}$ & $\mathrm{Mn}$ & $\mathrm{Cr}$ & $\mathrm{Al}$ & $\mathrm{Cu}$ & $\mathrm{P}$ & $\mathrm{S}$ & $\mathrm{W}$ \\
\cline { 2 - 11 } & 1,03 & 1,284 & 0,75 & 0,08 & $<0,01$ & 0,142 & $<0,04$ & 0,110 & 0,449 \\
\hline 2,0 & 2,49 & 1,386 & 0,81 & 0,05 & $<0,01$ & 0,140 & $<0,04$ & 0,109 & 0,360 \\
\hline 5,0 & 4,77 & 1,118 & 0,68 & 0,08 & $<0,01$ & 0,093 & $<0,04$ & 0,098 & 0,480 \\
\hline 10,0 & 6,75 & 1,210 & 0,73 & 0,06 & $<0,01$ & 0,101 & $<0,04$ & 0,105 & 0,515 \\
\hline 15,0 & & &
\end{tabular}


Due to these results the fraction of adopted molybdenum could be calculated, calculated values are used for drawing functional dependence of mass fraction of the $\mathrm{MoO}_{3}$ powder versus yield of molybdenum recovery in the alloys. On the Figure 4 is showed this functional dependence.

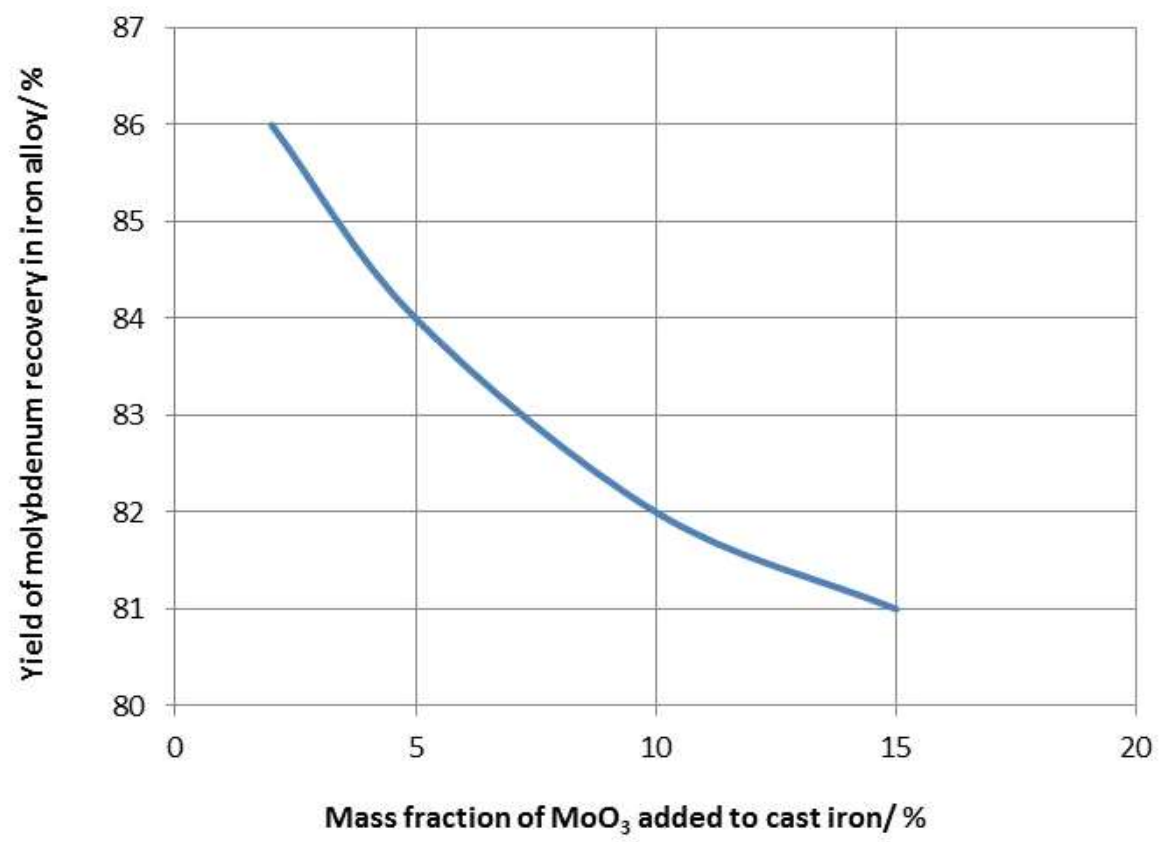

Figure 4. Change in yield of molybdenum recovery as function of amount of added $\mathrm{MoO}_{3}$ in a cast iron

Slika 4. Zavisnost stepena iskorišćenja molibdena kao funkcija količine dodatog $\mathrm{MoO}_{3}$ u sivi liv

It is clear that increasing amount of molybdenum (VI) - oxide results in decreasing yield recovery in alloyed cast iron. This may be because of too fast importation the $\mathrm{MoO}_{3}$ into the melted cast, so molybdenum didn't succeed to diffuse in the whole cast and stay onto the surface together with slag.

Mass fraction of molybdenum increases together with increase in amount of $\mathrm{MoO}_{3}$ added to the cast, which consequently increase the hardness of cast iron. On the Figure 5 is showed dependence of mass fraction of $\mathrm{MoO}_{3}$ added versus measured Brinell hardness.

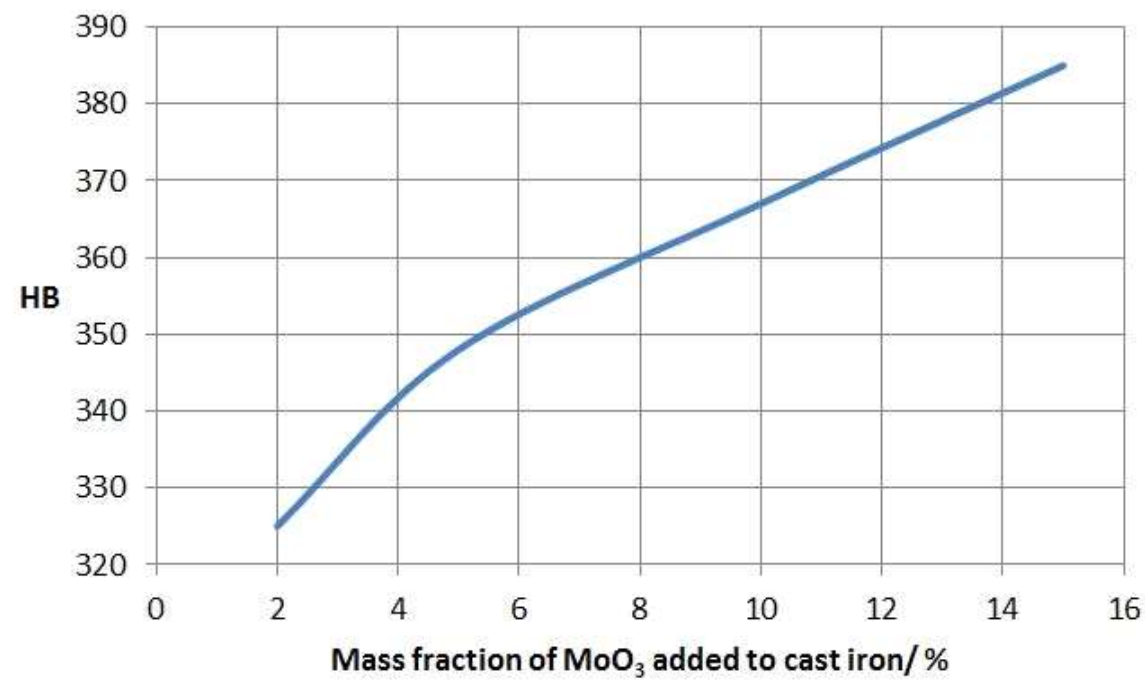

Figure 5. Measured Brinell hardness of the iron alloy samples as a function of $\mathrm{MoO}_{3}$ mass fraction

Slika 5. Funkcija izmerene tvrdoće po Brinelu uzoraka železne legure u zavisnosti od masenog udela $\mathrm{MoO}_{3}$ 
- Right after cooling the alloyed samples of cast iron, metallography examination has been performed; the results of this characterizing method were following:

- Sample with 2,0 mass \% of $\mathrm{MoO}_{3}$ : On the surface of the sample was extracted very fine graphite, its phase composition was very fine ledeburite $45 \%$ (a mixture of $25 \%$ ledeburite cementite and $20 \%$ of paerlite) $+55 \%$ of martensite

- Sample with 5,0 mass \% of $\mathrm{MoO}_{3}$ : Graphite wasn't extracted on the surface, and its phases was $30 \%$ ledeburite cemetite $+50 \%$ of paerlite $+20 \%$ of martensite.

- Sample with 10 mass \% of $\mathrm{MoO}_{3}$ : Graphite wasn't observed on the surface of the sample, phase composition was $35 \%$ of ledeburite cementite $+65 \%$ of bainite

- Sample with 15 mas \% of $\mathrm{MoO}_{3}$ : There was no graphite on its surface, its phases were very fine ledeburite with $30 \%$ of ledeburite cementite $+70 \%$ of bainite

\section{CONCLUSIONS}

In the present work, the molybdenum recovery process using ammonia gas neutralization of spent acid was successfully implemented by producing a commercial grade molybdenum ( $\mathrm{VI}$ )-oxide powder (Mo content of 59,2 mas \%). The overall molybdenum yield from the waste acid solution was calculated to be $92 \%$. This synthesized powder was successfully implemented as alloying agent of grey cast iron. Increasing the mass fraction of the $\mathrm{MoO}_{3}$ to the grey cast iron resulted in increasing of the hardness of iron alloy samples from $325 \mathrm{HB}$ for the lowest molybdenum content to $386 \mathrm{HB}$ for the highest molybdenum content. Also increasing the mass fraction of molybdenum leads to decreasing the yield of molybdenum recovery in iron alloy. Molybdenum yield of recovery in iron alloy was as high as $86 \%$ and it was accomplished with using the smallest amount of $\mathrm{MoO}_{3}$ powder.

\section{Acknowledgements}

The authors wish to acknowledge the financial support from the Ministry of Education, Science and Technological Development of the Republic of Serbia through the projects TR34023 and TR34002.

\section{REFERENCES}

[1] J.J.Pak, J.O.Jo, C.H.Park, J.G.Kang, D.H.Shin (2008) Recovery of Molybdenum from Spent Acid by Ammonia Gas Neutralization, Mater Trans, 49 (1), 202-207.
[2] H.Liu, C.Hu, X.Sun, Q.Tan, Z.Nie, X.Hu (2010) Interactive effects of molybdenum and phosphorus fertilizers on photosynthetic characteristics of seedlings and grain yield of Brassica napus, Plant Soil, 236 (1-2), 345-353.

[3] X.C.Sun, C.X.Hu, Q.L.Tan, Q.Q.Gan (2006) Effects of molybdenum on photosynthetic characteristics in winter wheat under low temperature stress, Agric. Sci. China, 32, 1418-1422.

[4] K.H.Park, B.R.Reddy, D.Mohapatra, C.W.Nam (2006) Hydrometallurgical processing and recovery of molybdenum trioxide from spent catalyst, Int $\mathrm{J}$ Miner Process, 80, 261-265.

[5] D.D.Sun, J.H.Tay, H.K.Cheong, D.L.K.Leung, G. Qian (2001) Recovery of heavy metals and stabilization of spent hydrotreating catalyst using a glass-ceramic matrix, J. Hazard. Mater., 87(1), 213223.

[6] B.B.Kar, B.V.R.Murthy, V.N.Misra (2005) Extraction of molybdenum from spent catalyst by salt-roasting, Int J Miner Process, 76, 143-147.

[7] B.B.Kar, P.Datta, V.N.Misra (2004) Spent catalyst: Secondary source for molybdenum recovery, Hydrometallurgy, 72, 87-92.

[8] J.M.Laferty (2005) Molybdenum and Molybdenum Compounds, knjiga Ullmann's Enc. of Industrial Chemistry, Izdavač Wiley-VCH Verlag GmbH \& Co. KGaA, Weinheim, p 15992.

[9] U.S.Geological Survey (2010) Mineral Commodity Summaries, Molybdenum, p. 107.

[10] T.A.Lasheen, M.E.El-Ahmady, H.B.Hassib, A.S Helal (2013) Oxidative leaching kinetics of molybdenum-uranium ore in $\mathrm{H}_{2} \mathrm{SO}_{4}$ using $\mathrm{H}_{2} \mathrm{O}_{2}$ as an oxidizing agent, Front Chem Sci Eng, 7 (1), 95102.

[11] M.K.Trivedi, R.M.Tallapragada, A.Branton, D. Trivedi, G.Nayak, O.Latiyal, S.Jana (2015) Analysis of Physical, Thermal, and Structural Properties of Biofield Energy Treated Molybdenum Dioxide, IJMSA, 4 (5), 354-359.

[12] Y.Ono (2003) A survey of the mechanism in catalytic isomerization of alkanes, Catal Today, 81 (1), 3-16.

[13] C.Song, M.Khanfar, P.G.Pickup (2006) Mo oxide modified catalysts for direct methanol, formaldehyde and formic acid fuel cells, J Appl Electrochem, 36 (3), 339-345.

[14] K.Bundschuh, M.Schüze, C.Müller, P.Greil, W. Heider (1998) Selection of Materials for Use at Temperatures above $1500^{\circ} \mathrm{C}$ in Oxidizing Atmospheres, J Eur Ceram Soc, 18(16), 2389-2391.

[15] http://web.archive.org/web/20120310004452/h ttp://www.Ime.com:80/minormetals/ 6782.asp

[16] A.D.Kulkarni, Recovery of molybdenum from "spentacid", Metall. Mater. Trans. B, 7(1), 115-118. 
[17] L.V.McCarty (1981) Proceedings of a Symposium at the 11th AIME Annual Meeting, Chicago, Illinois, knjiga radova, p. 45-53.

[18] T.A.Velikanova, M.V.Karpets, S.U.Artyukh, S.O. Balanetskii, V.M.Petyukh, P.G.Agraval, M.A. Turchanin (2011) Projection of the solidus surface of the $\mathrm{Fe}-\mathrm{Mo}-\mathrm{C}$ system in the composition range 0-40 at.\% C, Powder Metall Met Ceram, 50(7-8), $442-451$.

[19] T.Rosenqvist (2004) Principles of Extractive Metallurgy, Tapir Academic Press, Trondheim, p.53.

[20] M.Gavrilovski, V.Manojlović, Ž.Kamberović, M. Korać, M.Sokić (2014) Semi-empirical software for the aluminothermic and carbothermic reactions, Metall. Mater. Eng., 20(3), 199-206.

[21] A.Chychko, L.Teng, S.Seetharaman (2010) $\mathrm{MoO}_{3}$ Evaporation Studies from Binary Systems towards Choice of Mo Precursors in EAF, Steel Res Int, 81 (9), 784-791.

[22] A.Chychko, L.Teng, M.Nzotta, S.Seetharaman (2011) Synthesis and Characterization of $\mathrm{Fe}_{2} \mathrm{MoO}_{4}$ as a Precursor Material for Mo Alloying in Steel, Steel Res Int, 82 (3), 269-276.

[23] H.R.Heytmeijer (1981) Rapid and Efficient Recovery of Molybdenum from Spent Mandrel Dissolving Acid Solution. USA Patent, 4307065.

\section{IZVOD}

\section{VALORIZACIJA MOLIBDENA IZ OTPADNOG MOLIBDENSKOG RASTVORA ZA LEGIRANJE SIVOG LIVA}

$U$ istraživačkom radu opisan je komercializovan reciklažni proces prerade otpadnog rastvora iz postrojenja za proizvodnju sijaličnih vlakana od volframa radi izdvajanja molibden (VI)-oksida i njegovom daljem iskorišćavanju kao legirajućeg agensa sivog liva. U prvom delu izvršena je neutralizacija utrošene kiseline, koja u sebi sadrži izvesne količine molibdena, uz pomoć rastvora amonijaka, a potom kristalizacija i filtracija amonijum-molibdata, njegovo sušenje $i$ prženje u cilju dobijanja praha molibdentrioksida tehničke čistoće (maseni udeo molibdena 59,2 mas\%). U drugom delu izvršeno je legiranje sivog liva uz pomoć $\mathrm{MoO}_{3}$ u indukcionoj peći. Finalni proizvod je legura železa sa povećanom tvrdoćom uz postignut visok stepen usvajanja molibdena u leguri (čak do 86\%).

Ključne reči: otpadni rastvor, neutralizacija amonijakom, molibdentrioksid, legiranje, sivi liv.

\section{Naučni rad}

Rad primljen: 31. 10. 2017.

Rad prihvacen: 30. 11. 2017.

Rad je dostupan na sajtu: www.idk.org.rs/casopis

(c) 2018 Authors. Published by Engineering Society for Corrosion. This article is an open access article distributed under the terms and conditions of the Creative Commons Attribution 4.0 International license (https://creativecommons.org/licenses/by/4.0/) 